\title{
The Quantity and Volume Dynamics of Unauthorized Money Transfers in Russia
}

Anton V. GOLUB ${ }^{1}$ and Natalia A. SHCHUKINA ${ }^{2}$

${ }^{1}$ System Architect, QIWI Plc, Moscow, Russia

${ }^{2}$ Plekhanov Russian University of Economics, Moscow, Russia

${ }^{2}$ Financial University under the Government of the Russian Federation, Moscow, Russia

Correspondence should address to: Natalia A. SHCHUKINA; shchukinan@yandex.ru

Received date: 11 February 2020; Accepted date: 10 July 2020; Published date: 27 August 2020

Copyright (C) 2020. Anton V. GOLUB and Natalia A. SHCHUKINA. Distributed under Creative Commons Attribution 4.0 International CC-BY 4.0

\begin{abstract}
The purpose of the study is to analyze the trends in the unauthorized transactions quantity and volume for the funds transfer by individuals through payment cards. The information base is the official data of the Central Bank of Russia for 2014-2019. To analyze trends and evaluate changes in the quantity and volume of transactions made without the consent of financial organizations clients, trend equations are constructed that are characterized by sufficient reliability. Trends in the volume of unauthorized transactions in the context of the place of commitment are considered separately: retail organizations, ATMs and CNP transactions, as well as types of trends. In addition to the trend equations, the Holt-winters model was used to construct the forecast values of the indicators under consideration, which showed better results. Trends in the volume of unauthorized transactions in the context of the place of commitment are highlighted separately: retail organizations, ATMs, and CNP transactions, as well as types of trends. The analysis showed that stable pattern indicators are still being formed. Therefore, the creation and implementation of an effective strategy for the development of the banking sector, in modern conditions, along with the traditional introduction of new, innovative approaches to risk assessment and management in a specific sphere of activity.
\end{abstract}

Keywords: unauthorized operations, payment cards, the trend analysis, the digitalization of the economy, cyber security, the risk.

JEL Classification: C53; C15

Cite this Article as: Anton V. GOLUB and Natalia A. SHCHUKINA (2020)," The Quantity and Volume Dynamics of Unauthorized Money Transfers in Russia " Journal of EU Research in Business, Vol. 2020 (2020), Article ID 428851, DOI: 10.5171/2020.428851 


\section{Introduction}

One of the key issues of the Information Society Development Strategy in the Russian Federation for 2017-2030 (Presidential Decree, 2017) is the formation of a national digital economy. The corresponding Program for the period 2017-2024 (Order of the Government of Russia, 2017) with an annual estimated budget of 100 billion rubles was adopted. The country's economy's transition to the digital development trajectory implies "support for the development of both existing conditions for the emergence of breakthrough and promising cross-cutting digital platforms and technologies, and the creation of conditions for the emergence of new platforms and technologies" (Order of the Government of Russia, 2017). The banking sector is one of the most important structures of a market economy, which in the context of its digitalization requires a new principle of transition from an operational response to risk management, prevention and prevention of new negative factors, risks and threats. One of the conditions for the successful implementation of this principle is the development of the skills of the digital economy, the digital education and R\&D system, investment in digital infrastructure and cybersecurity (Report on the Russian economy, 2017).

The formation and implementation of an effective development strategy for the banking sector in modern conditions requires the introduction of international standards for risk assessment and management (COSO, 2017). Each country has risk management systems that take into account the peculiarities of organizational factors for introducing risk management in small and medium enterprises. One such study at the interstate level was conducted by Henschel and Durst (2016). adjusted for the Russian market, as well as the creation and implementation of new science-based models and methods in its specific field of activity. Features of the Russian risk management system are reflected in the works of Barilenko (2016), Ankina (2017), Lanskov and Zenkovich (2017). The choice of the mathematical apparatus for modeling decision-making processes is largely determined by the degree of uncertainty of environmental factors with the strong dependence of Russian economy indicators on them.

\section{Materials and Methods}

The complexity and inconsistency of domestic and global socio-economic processes lead to the expansion of the risk zone. The evolution of banks in the emerging digital economy involves the introduction of new organizational forms. This also induces the emergence of new banking risks. Classic banking is undergoing change. Cash gives way to non-cash payments. At the same time, in terms of volume, such operations occupy $68 \%$ of the market. In general, in the first half of 2019, individuals used their cards 19.2 billion times for a total of more than 40 trillion rubles. This is primarily due to the growth of online commerce. In 2018, the turnover of online trading in Russia amounted to 1.5 trillion. rubles. Figure 1 shows the dynamics of the use of payment cards in Russia and abroad. 


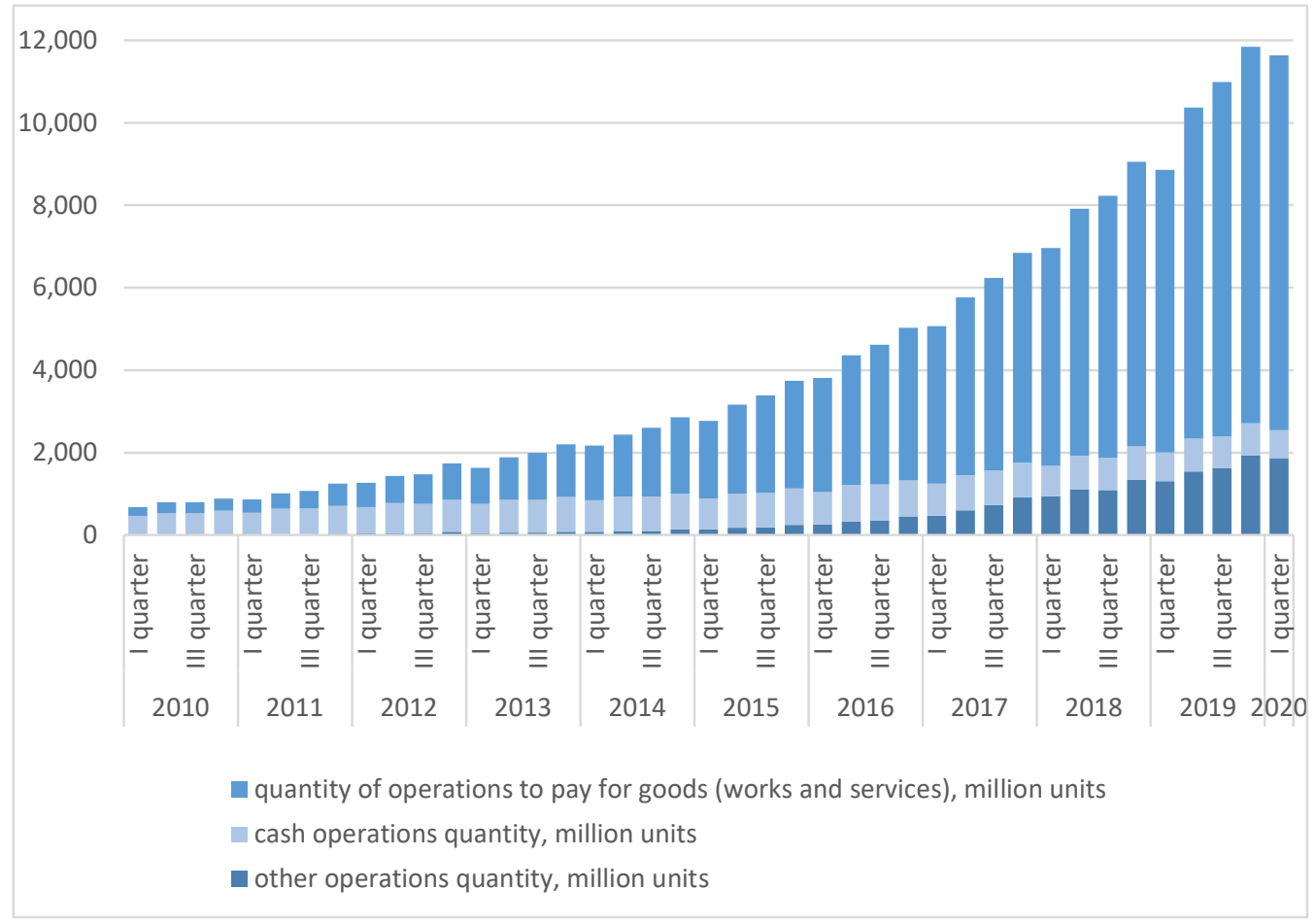

Fig 1. Operations using payment cards committed in Russia and abroad Source: Authors at Bank of Russia, https://www.cbr.ru/statistics/nps/psrf/

The most popular payment methods through the Robokassa platform in 2018 were bank cards, electronic money, Qiwi-wallets, mobile payments of all major operators, Internet banking, payments through Euroset and Svyaznoy salons. The distribution of payment methods for online purchases in the total volume of non-cash transactions is presented in Figure 2.

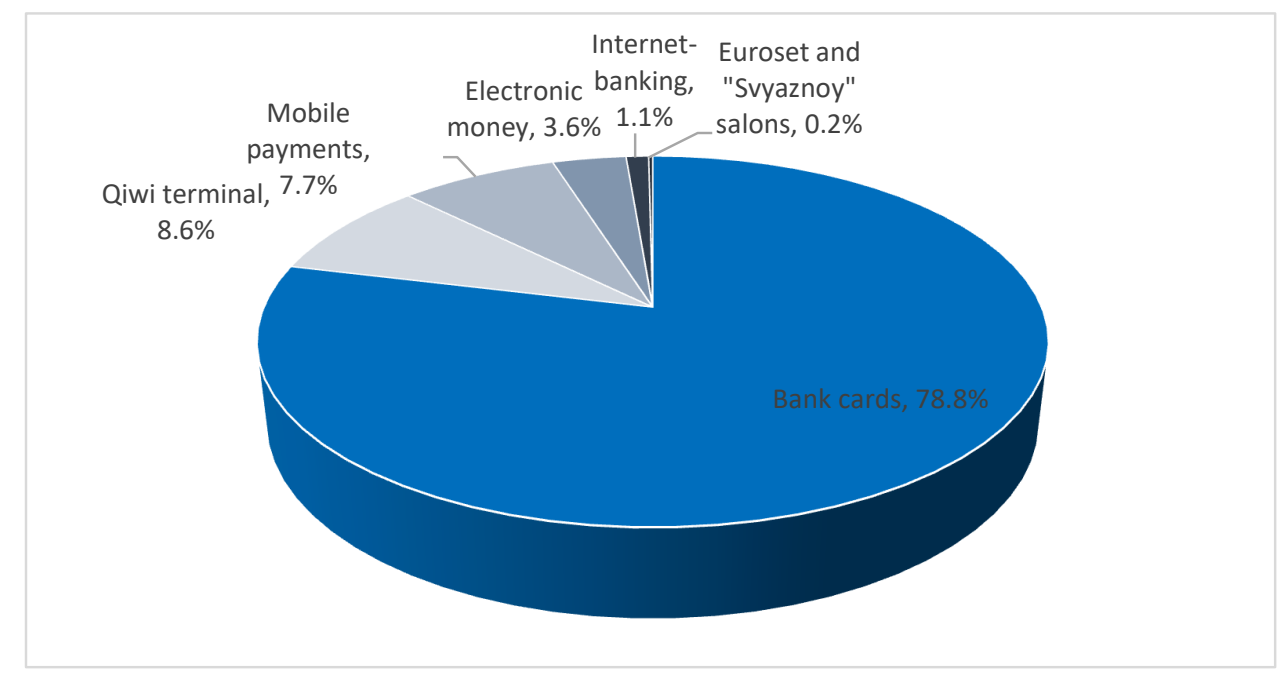

Source: Authors

Fig 2. The most popular payment methods

Anton V. GOLUB and Natalia A. SHCHUKINA (2020), Journal of EU Research in Business, DOI: $10.5171 / 2020.428851$ 
Bank cards are the leader in terms of cashless payments, which can easily be explained by their wide distribution. According to the statistics of the Bank of Russia, more than $90 \%$ of transactions on cards of Russian citizens in the first half of 2019 were made by non-cash transactions: payment for goods and services, as well as transfers from card to card / bank account / deposit. The level of provision of the population with payment infrastructure is growing every year, and as of July 1, 2019, for 1 million inhabitants, there were 21 thousand devices for receiving payment cards. The dynamics of the quantity and volume of transactions using payment cards in the Russian Federation is presented in Figure 3.

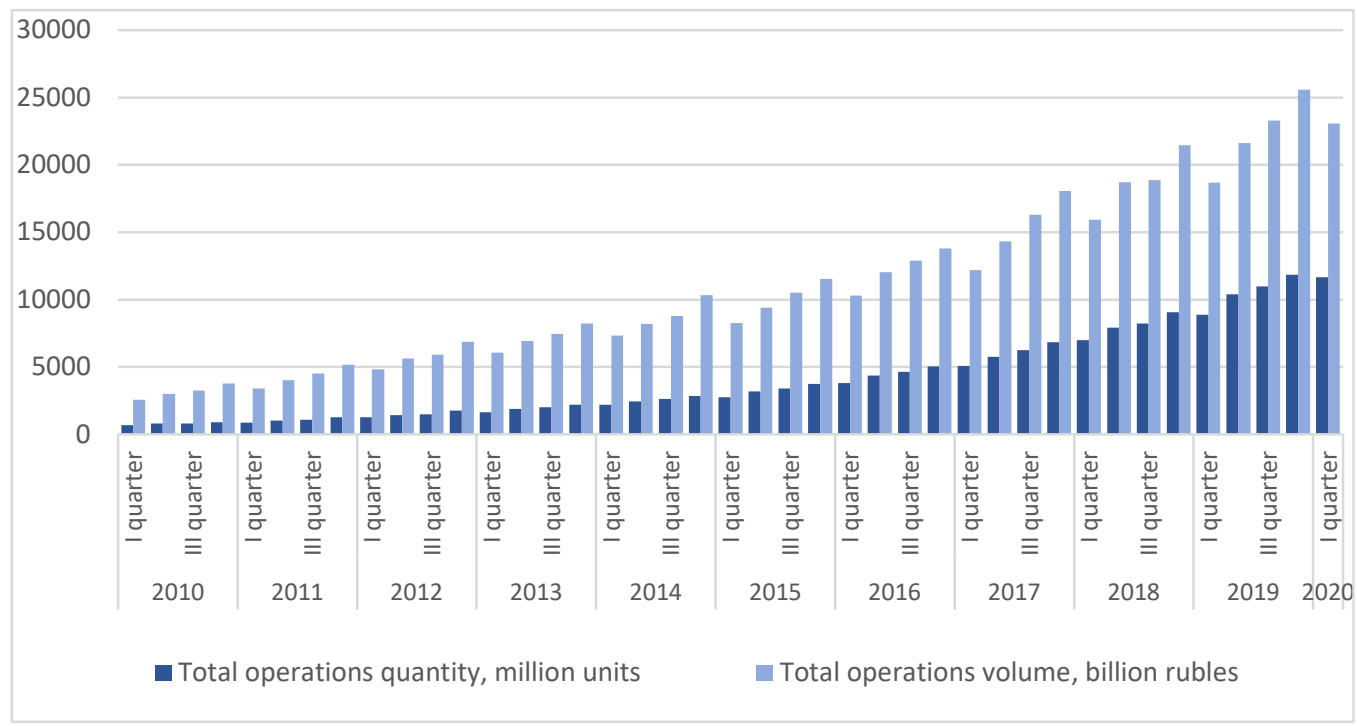

Fig 3. Dynamics of transactions quantity and volume using payment cards in the Russian Federation (including operations abroad)

Source: Authors at Bank of Russia, https://www.cbr.ru/statistics/nps/psrf/

The risk of unauthorized transfers of funds by individuals using payment cards is increasing. The complexity of assessing such a risk is due to the blurring of the boundary of the operational risk category, to which it can be attributed in accordance with the agreement of the Basel Committee on Banking Supervision. In order to develop scientifically based recommendations on ways, means and methods to increase the effectiveness and efficiency of risk assessment and risk management processes, internal control and cybersecurity in the field of banking operations, it is first necessary to analyze information on the quantity and volumes of unauthorized money transfer operations. We take the indicators of bank reporting as a basis for this analysis.

\section{Results}

At the first stage of work, we studied the dynamics of the quantity and volume of unauthorized operations conducted in Russia and abroad using payment cards. The report presents quarterly data sets for the period $2014-2018$.

In 2014, the total amount of unauthorized transactions committed using payment cards amounted to $1,581.4$ million rubles (Review of unauthorized transfers of funds, 2016). In 2015, this indicator reached a value of 1,147 million rubles, which is $72.53 \%$ of its previous value. In 2016, the indicated volumes amounted to 1075.4 million rubles; in comparison with 2014, this is $68 \%$, and compared to the previous year - 93.76\%. In 2017, the emerging downward trend continued: in comparison 
with 2014, the volume of unauthorized transactions committed using payment cards amounted to $60.79 \%$, and compared to the previous year $-89.39 \%$. According to (Review of unauthorized transfers of funds, 2017), the volume of unauthorized operations using payment cards in 2017 amounted to 961.3 million rubles. The volume of all unauthorized operations committed using payment cards issued in the Russian Federation in 2018 amounted to 1384.7 million rubles, which is $44 \%$ more than the same indicator in 2017 (961.3 million rubles). The quantity of such operations for the reporting period in 2018 amounted to 416,933 units, which is $31.4 \%$ more than the same indicator for 2017 $(317,178)$ (Review of unauthorized transfers of funds, 2018). In 2019, the volume of all transactions made without the consent of customers using payment cards amounted to 5723.5 million rubles, which is more than 4 times higher than the same indicator for 2018. The quantity of such operations increased to 571957 units (Review of unauthorized transfers of funds, 2019). The dynamics of quarterly data on the quantity and volumes of unauthorized payment cards operations conducted on the territory of Russia is presented in Figure 4.

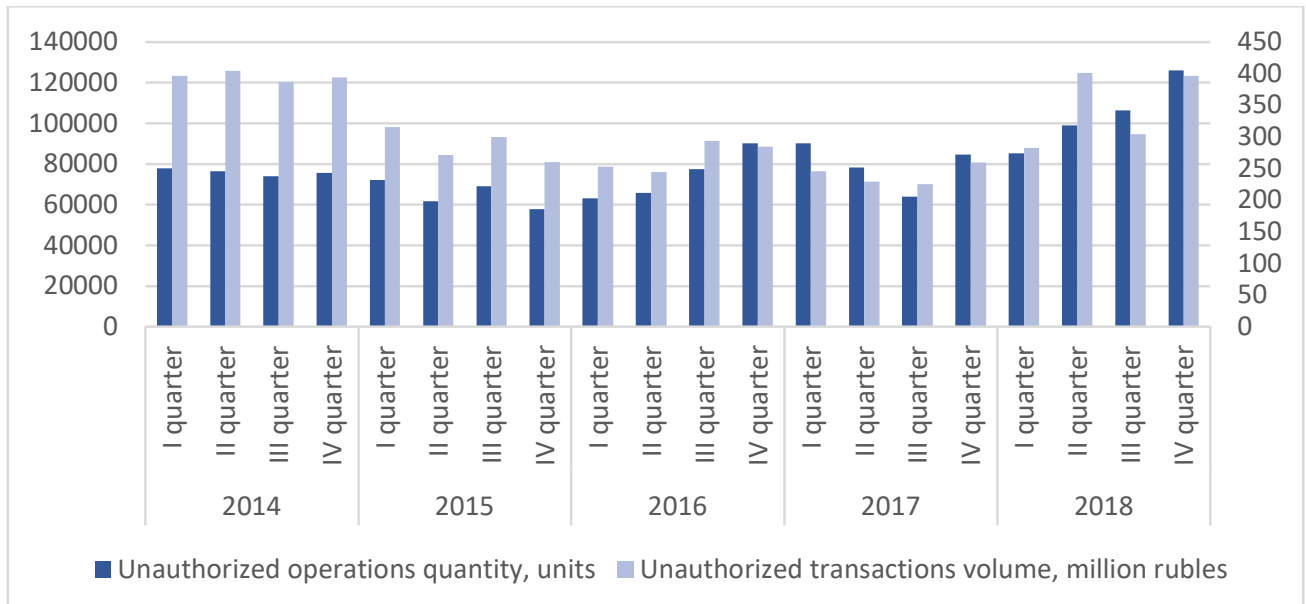

Fig. 4. Unauthorized transactions quantity and volume using payment cards

Source: Authors at Review of unauthorized transfers of funds

Figures 3 and 4 show that the quantity of unauthorized transfers of funds by individuals is increasing against the background of an increase in the quantity of transactions using payment cards. An analysis was also made of the quarterly values of the volume of unauthorized transactions committed using payment cards. Its graphical interpretation is shown in Figure 5. From Figure 5 it can be seen that in some periods the volume of unauthorized operations tends to decrease. However, in 2018, the data showed an increase in the quantity and volume of thefts in 2018. 


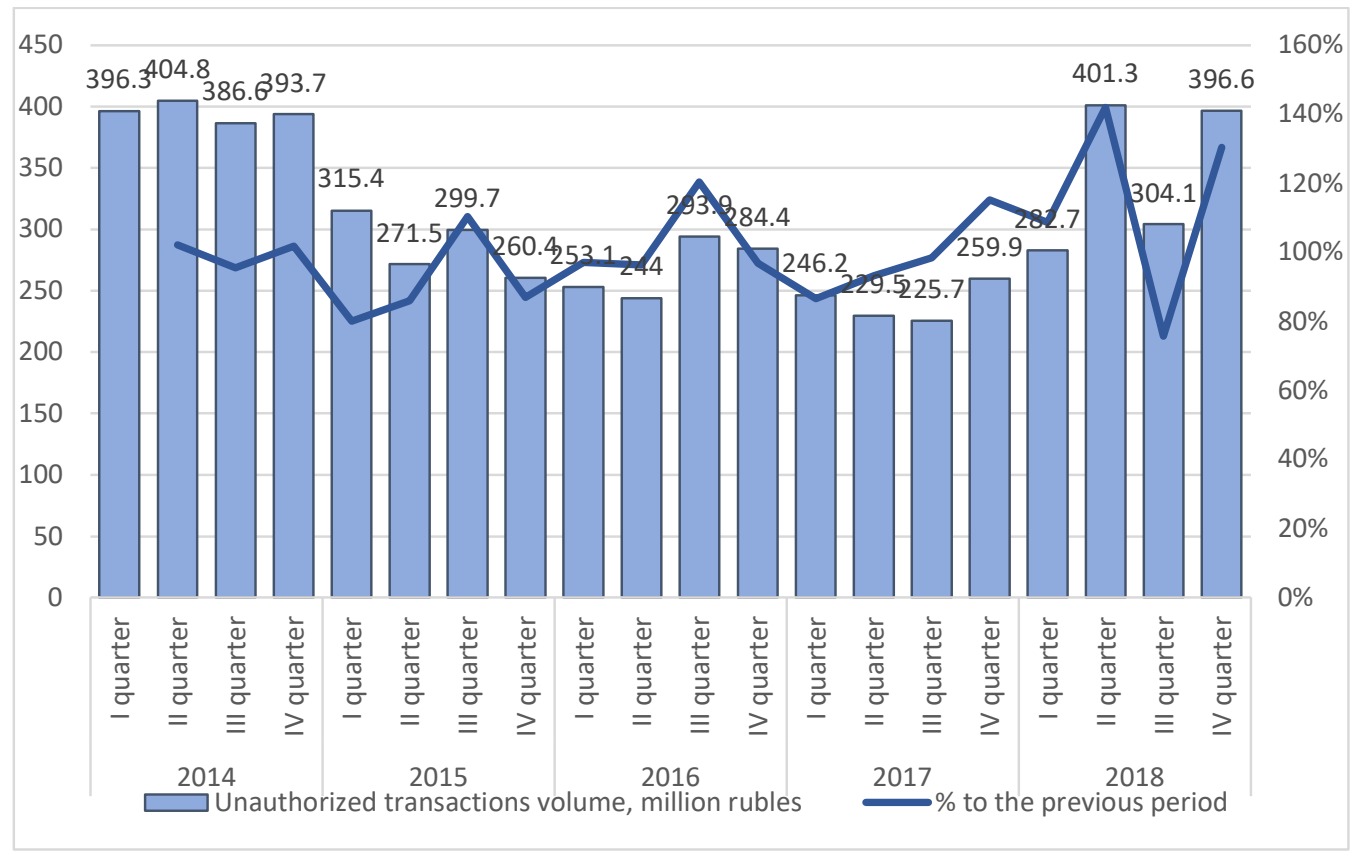

Fig 5. Unauthorized transactions volume, million rubles

Source: Authors at Review of unauthorized transfers of funds

According to the indicators of bank reporting, in the period 2014 - 2015 there is a slight decrease in the quantity of unauthorized operations. However, from the fourth quarter of 2015 to the fourth quarter of 2016, the quantity of these operations from 57,929 increases to 90,277 units per quarter. The first three quarters of 2017 are characterized by a decrease in the indicator to 64089 units per quarter, but in the IV quarter there is a sharp increase in the quantity of unauthorized transactions using payment cards to 84,559 units, which reaches the third highest value for the entire period under review. At the same time, the average amount of one unauthorized operation in 2016 amounted to 3.62 thousand rubles. The average amount of one unauthorized operation in 2018 increased by $9.6 \%$ and amounted to 3.32 thousand rubles against 3.03 thousand rubles in 2017. This increase is due not only to an increase in the quantity and volume of unauthorized transactions in the reporting period, but also to an increase in the quantity of detections of these operations in the total quantity of transactions completed.
It should be noted that the share of the volume of unauthorized transactions in the total volume of transactions performed using payment cards in 2018 amounted to $0.0018 \%$ compared to $0.0016 \%$ in 2017 (Fig. 6). In general, for this indicator we can observe a steady downward trend. The calculation of the coefficients of the trend equation allowed us to obtain a nonlinear equation $y_{t}=(4.9 \ln (t)-1.1) 10^{-5}$, which shows that in 2019 we should expect a decrease in the share of the volume of unauthorized operations to $0.0013 \%$. Despite the results of the forecast and the emerging trend towards a decrease in the share of unauthorized operations, in 2019, this indicator increased again and amounted to $0.0023 \%$. Thus, we can note that stable trends have not yet been formed. The analysis results indicate the real need to increase the transparency of information provided by banks and confirm the feasibility of developing and implementing measures to minimize the risk of transactions without the consent of customers. 


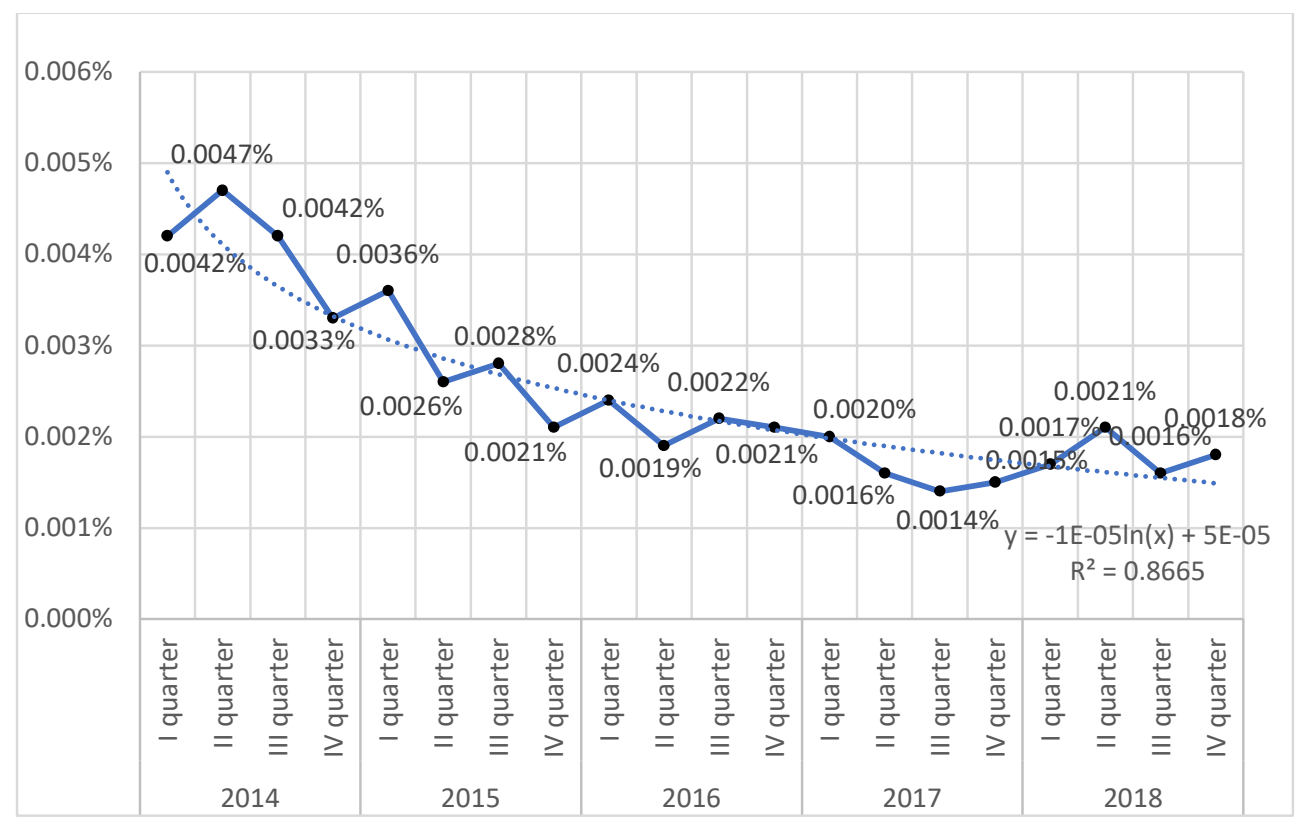

Fig 6. Share of unauthorized operations in the total transactions volume committed using payment cards, $\%$

Source: Authors at Review of unauthorized transfers of funds

To estimate and obtain a forecast for 2019 of the quantity and volume of unauthorized transactions using payment cards conducted on the territory of Russia and outside it, we construct the trend equations. The results of the regression analysis are presented in table 1.

Table 1: Regression analysis results of the unauthorized transactions quantity and volume using payment cards

\begin{tabular}{|l|l|l|c|c|c|c|}
\hline \multirow{2}{*}{\multicolumn{1}{|c|}{ Indicator }} & Trend & $\begin{array}{c}\text { I } \\
\text { quarter } \\
\mathbf{2 0 1 9}\end{array}$ & $\begin{array}{c}\text { II } \\
\text { quarter } \\
\mathbf{2 0 1 9}\end{array}$ & $\begin{array}{c}\text { III } \\
\text { quarter } \\
\mathbf{2 0 1 9}\end{array}$ & $\begin{array}{c}\text { IV } \\
\text { quarter } \\
\mathbf{2 0 1 9}\end{array}$ & $\begin{array}{c}\text { Total } \\
\mathbf{2 0 1 9}\end{array}$ \\
\hline $\begin{array}{l}\text { Unauthorized } \\
\text { transactions } \\
\text { quantity using } \\
\text { payment cards, } \\
\text { units }\end{array}$ & $\begin{array}{l}y_{t} \\
=41952 \\
+3103 t\end{array}$ & 107115 & 110218 & 113321 & 116424 & 447078 \\
\hline $\begin{array}{l}\text { Unauthorized } \\
\text { transactions } \\
\text { volume using } \\
\text { payment cards, } \\
\text { million rubles }\end{array}$ & $\begin{array}{l}y_{t} \\
=138.09\end{array}$ & 351.03 & 361.17 & 371.31 & 381.45 & 1464.96 \\
\hline
\end{tabular}

Source: Authors

The linear trend does not adequately describe the current dynamics in the quantity and volume of unauthorized transactions using payment cards conducted in Russia. For processes with a changing trend, the best forecast result is provided by adaptive models, which include, for example, the Brown model (1956), the Holt model (1957), etc. The forecasting trend approach involves 
extrapolating the aligned values of the dynamic time series of the predicted indicator, i.e. transferring past trends of the predicted indicator to its future development. The reliability of forecasts in this case depends on the stability of the trend of demand changes, which may be violated in the conditions of crisis development of the economy.

One of the simplest adaptive methods for short-term forecasting of irreversible processes is Brown's exponential smoothing method, the idea of which is to

$$
\left\{\begin{array}{c}
L_{t}=\alpha \frac{y_{t}}{S_{t-s}}+(1-\alpha)\left(L_{t-1}-T_{t-1}\right) \\
T_{t}=\beta\left(L_{t}-L_{t-1}\right)+(1-\beta) T_{t-1} \\
S_{t}=\gamma \frac{y_{t}}{L_{t}}+(1-\gamma) S_{t-s}
\end{array}\right.
$$

determine the next predicted value through the previous predicted value, adjusted by the deviation of the actual value from the predicted value (Brown, 1956). The HoltWinters model (Winters, 1960) is a modification of the Holt method (Holt,1957) and is used to predict time series in the structure of which there is an established trend and seasonality. This model is threeparameter and takes into account the smoothed exponential series, trend and season and consists of a system of recurrence equations:

where $\alpha \in[0 ; 1], \beta \in[0 ; 1], \gamma \in[0 ; 1]$ - smoothing constants;

$L_{t}, L_{t-1}$ - the smoothed values for the current and previous periods, respectively; $T_{t}, T_{t-1}$ - trend value for the current and previous periods, respectively;

$S_{t}, S_{t-1}$ - seasonality for the current period and for the same period in the previous season, respectively.

$$
\hat{y}_{t+p}=\left(L_{t}+p T_{t}\right) S_{t-s+p} \text {, }
$$

where $S_{t-s+p} \quad$ - the value of the seasonal component for the same period in the last season.

To build a forecast of the quantity dynamics of unauthorized operations using payment cards for the first half of 2019 , as the initial value we choose the data on the quantity of unauthorized operations in the first quarter of 2017, for which we assume $\mathrm{p}=1$. We choose the smoothing constants $\alpha \in[0 ; 1]$, $\beta \in[0 ; 1], \quad \gamma \in[0 ; 1]$ to minimize the average relative forecast error. For the initial data of the levels of the considered time series, we obtain $\alpha=0.835, \beta=0.635, \gamma$ $=0.5$. The approximation error of the HoltWinters model is $\bar{O}=\frac{1}{n} \sum \frac{\left|y_{t}-\widehat{y_{t}}\right|}{y_{t}}=0.046$, which indicates the high quality of the forecast. Based on the simulation results, we obtained the following values of the quantity of unauthorized transactions using payment cards for the first half of 2019: in
For the first period, the exponentially smoothed series is equal to the first value of the series: $L_{1}=y_{1}$. Seasonality in the first and second period is $1: S_{t-s}=1$. The trend value for the first period is $0: T_{1}=0$. Then the forecast for $\mathrm{p}$ periods is

the first quarter - 123289 units, in the second quarter - 124707 units.

To build a forecast of the volume dynamics of unauthorized operations using payment cards for the first half of 2019, we choose the data on the quantity of unauthorized operations in the first quarter of 2017 for which we set $p=1$. For the initial data of the levels of the considered time series, we obtain $\alpha=0.835, \beta=0.835, \gamma=1$. The approximation error of the Holt-Winters model is $\bar{O}=\frac{1}{n} \sum \frac{\left|y_{t}-\widehat{y_{t}}\right|}{y_{t}}=0.068$, which indicates the high quality of the forecast. The result of modeling (1) and building a forecast (2) is as follows: in the first quarter of 2019, the volume of unauthorized transactions using payment cards is forecasted at 429.89 million rubles, in the second quarter -470.09 million rubles. 
The next stage of work explores the dynamics of unauthorized payment cards operations in the context of the execution place. These places are differentiated by the following groups: trade organizations, ATMs and CNP transactions (transactions performed via the Internet and mobile devices, including Internet banking). A histogram of the volumes of these operations is shown in Figure 8. In the total volume and quantity of unauthorized operations, the main share is made up of CNP transactions: in 2018, their share in the total volume of operations was $81.4 \%$, which is 5.8 percentage points more than in 2017 (75.6\%).
The dynamics of unauthorized operations for each group are investigated using trend highlighting. The trend hypothesis was confirmed in each group. To check the quality of the obtained nonlinear trend models, the tightness of the relationship through the correlation index was evaluated for each of them: $\rho_{t y}=\sqrt{1-\frac{\sum_{i=1}^{n}\left(y_{i}-\widehat{y t}\right)^{2}}{\sum_{i=1}^{n}\left(y_{i}-\bar{y}\right)^{2}}}$ and average approximation error: $\bar{A}=$ $\frac{1}{n} \sum_{i=1}^{n} \frac{\left|y_{i}-\widehat{y_{t l}}\right|}{y_{i}} \cdot 100 \%$,

where $y_{i}$ - actual row level value,

$\widehat{y_{t l}}$ - theoretical (calculated) value of the level of the series,

$\bar{y}$ - average of the actual levels of the series, $n$ - number of elements.

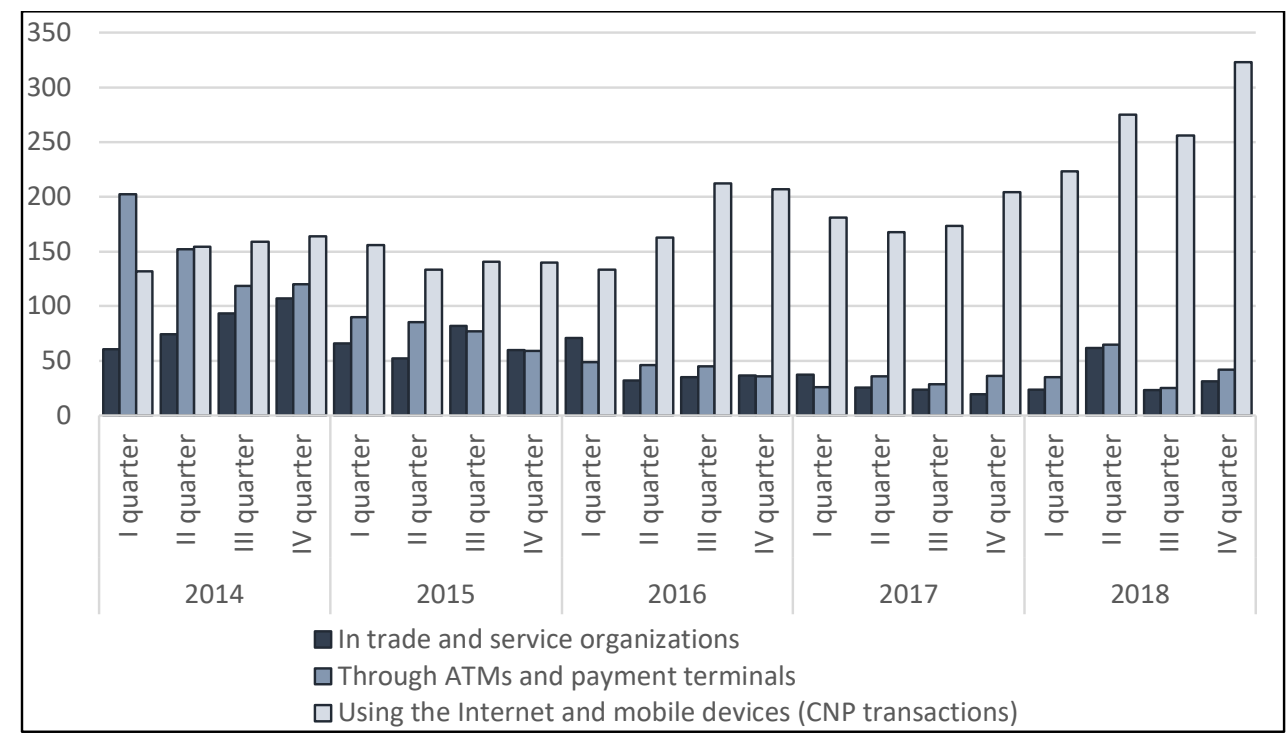

Fig. 8. Unauthorized transactions dynamics using payment cards in the context of their terms and conditions (million rubles)

Source: Authors at Review of unauthorized transfers of funds

Between the 1st quarter of 2014 and the 3 rd quarter of 2015, the volumes of unauthorized transactions carried out through ATMs and payment terminals are rapidly decreasing. Then, relative stability is observed, but the decline does not stop. This behavior is characteristic of both hyperbolic and logarithmic types of trend. Therefore, the standard procedure for clarifying the type of trend was carried out. Based on the results of a regression analysis for the volumes of unauthorized operations carried out through ATMs and payment terminals, the equation is obtained $y_{t}=186,86-$ $55,82 \ln (t)$.

For volumes of unauthorized operations using payment cards committed in trade and service organizations, the linear trend equation is: $y_{t}=85,19-3,27 t$.

For the volume of transactions made through the Internet and mobile devices, the 
equation of the exponential trend was obtained $y_{t}=123,13 \exp (0,0356 t)$.

It should be noted that, in contrast to the volumes of unauthorized transactions committed in trade organizations and through ATMs, the volumes of unauthorized CNP transactions tend to increase.
A feature of the consideration of the territorial distribution of unauthorized operations is their concentration on the territory of the Central Federal District. This is explained by the fact that the majority of credit organizations serving individuals are located in the Central Federal District (Table 2, Fig. 9).

Table 2: Unauthorized operations quantity and volume by Federal districts

\begin{tabular}{|l|c|c|c|c|c|c|c|c|}
\hline \multirow{2}{*}{$\begin{array}{c}\text { Federal } \\
\text { districts } \\
\text { and Federal } \\
\text { significance } \\
\text { cities }\end{array}$} & \multicolumn{5}{|c|}{$\begin{array}{c}\text { Quantity of unauthorized } \\
\text { operations, units }\end{array}$} & \multicolumn{3}{c|}{$\begin{array}{c}\text { Unauthorized transactions volume, } \\
\text { thousand rubles }\end{array}$} \\
\cline { 2 - 10 } & $\mathbf{2 0 1 6}$ & $\mathbf{2 0 1 7}$ & $\mathbf{2 0 1 8}$ & $\mathbf{2 0 1 9}$ & $\mathbf{2 0 1 6}$ & $\mathbf{2 0 1 7}$ & $\mathbf{2 0 1 8}$ & $\mathbf{2 0 1 9}$ \\
\hline Moscow & 65403 & 85819 & 138422 & 339522 & 27765 & 325540 & 522507 & 2593875 \\
\hline $\begin{array}{l}\text { Saint } \\
\text { Petersburg }\end{array}$ & 6410 & 5464 & 6705 & 13403 & 27629 & 19472 & 61429 & 402930 \\
\hline Central FD & 27224 & 28572 & 18858 & 46620 & 78925 & 56389 & 55718 & 287782 \\
\hline Volga FD & 20496 & 18810 & 19952 & 2613 & 54131 & 40016 & 52008 & 71852 \\
\hline Siberian FD & 15911 & 12915 & 13103 & 147 & 39336 & 23526 & 27985 & 949 \\
\hline Southern FD & 10619 & 8459 & 10689 & 527 & 30002 & 17595 & 26561 & 8170 \\
\hline Urals FD & 9895 & 9357 & 9374 & 4067 & 28037 & 19920 & 27126 & 90075 \\
\hline $\begin{array}{l}\text { North- } \\
\text { Western FD }\end{array}$ & 9756 & 10348 & 9183 & 134 & 27090 & 19725 & 17220 & 2123 \\
\hline Eastern FD & 7177 & 5801 & 5038 & 4057 & 23812 & 14588 & 24748 & 38517 \\
\hline $\begin{array}{l}\text { North } \\
\text { Caucasus FD }\end{array}$ & 3797 & 2208 & 1808 & 16 & 11946 & 3953 & 5060 & 207 \\
\hline
\end{tabular}

Source: Authors at Review of unauthorized transfers of funds

The leaders in the quantity and volume of unauthorized operations are Moscow and the Moscow region. In terms of the volume of unauthorized transactions using payment cards, $64 \%$ of the corresponding indicators in 2018 accounted for Moscow and in 2019 the volume of such transactions amounted to $74 \%$.
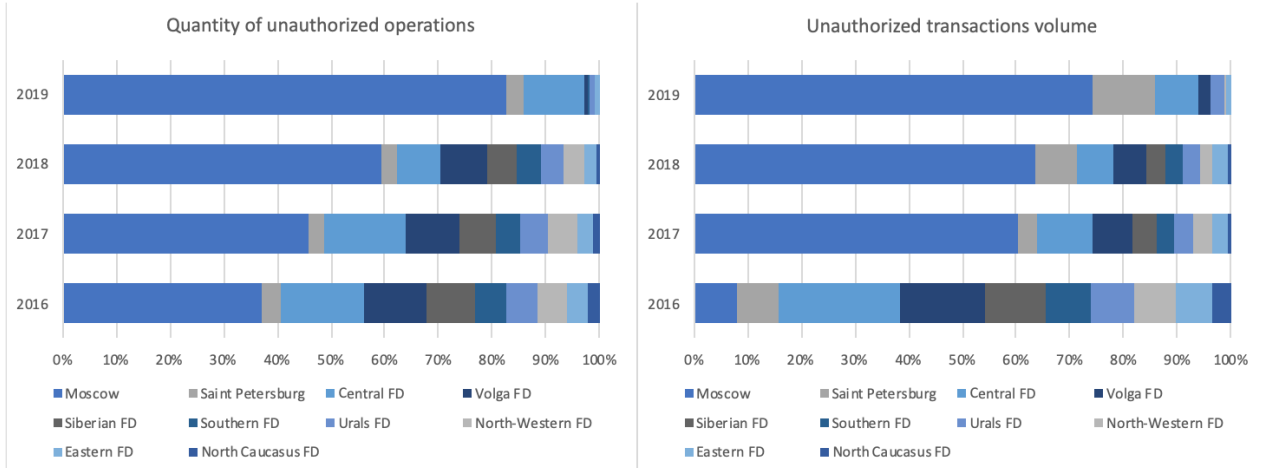

Fig 9. Unauthorized operations quantity and volume by Federal districts in 2016 - 2019 Source: Authors at Review of unauthorized transfers of funds 
Unauthorized transactions committed outside the Russian Federation account for $44 \%$ of the quantity and $40.7 \%$ of the volume of all unauthorized transactions committed in 2018. In 2017, these indicators were 40 and 44\%, respectively. In this regard, it is possible to predict the continuation of a trend in which the share of the volume and quantity of unauthorized operations committed in the Russian Federation in the total volume and quantity of all unauthorized operations is more than $50 \%$.

\section{Conclusion}

Summarizing the results of the study, we can draw the following conclusions. A nonlinear downward trend in the volume of unauthorized transactions committed using payment cards has been identified. Separately identified trends in the volume of unauthorized operations in the context of the place of their execution: trade organization, ATMs and CNP transactions. For volumes of unauthorized transactions committed through ATMs and payment terminals, a logarithmic trend is obtained. For volumes of unauthorized operations using payment cards committed in trade and service organizations, a linear trend model with a downward trend was obtained. For the volumes of transactions performed via the Internet and mobile communication devices, an equation of the exponential trend with an upward trend is obtained.

The analysis showed that for certain indicators it is difficult to obtain forecast values, since in the context of large-scale digitalization of the economy and the rapid development of information and financial technologies, stable patterns are still being formed. The results can be used by money transfer operators, as well as payment infrastructure service providers, to plan activities for risk management, internal control and information protection. Cybersecurity technologies should be prioritized.

\section{References}

- $\quad$ Ankina, A.A. (2017) 'Risk management in the activities financial organizations: Foreign and Russian experience.' Internet-journal 'Naukovedenie', 9 (3). [Online], [Retrieved December 20, 2019], https://naukovedenie.ru/PDF/117EV N317.pdf

- Barilenko, V.I. (2016), 'Business analysis and overcoming the "new normality" of the domestic economy', Management and business administration, 4, 44-50.

- Brown, R.G. (1956) Statistical forecasting for inventory control. McGraw-Hill. New York.

- COSO (2017) 'Conceptual framework for enterprise risk management: integration with strategy and business management' COSO 2017. [Online], [Retrieved December 20, 2019], https://www.coso.org/Pages/erm.asp $\mathrm{x}$

- Henschel, T., Durst, S. (2016) 'Risk management in Scottish, Chinese and German small and medium-sized enterprises'. International journal of entrepreneurship and small business, 29(1), 112-132.

- Holt, C.C. (1957) 'Forecasting Seasonals and Trends by Exponentially Weighted Moving Averages'. ONR Memorandum, 52, Carnegie Institute of Technology, Pittsburgh.

- Lanskov, P.M. and Zenkovich, E.V. (2017) 'Integrated system of internal control and risk management and internal audit in non-credit financial organizations', Money and credit, 2, 3436.

- Order of the Government of the Russian Federation of 28.07.2017. \# 1632-p. Official website of the Government of the Russian Federation. [Online], [Retrieved December 20, 2019], http://government.ru/docs/all/11283 1/

- Presidential Decree \# 203 of May 9, 2017 "On the Strategy for the Information Society Development in the Russian Federation for 2017-2030". Official website of the President of the 
Russian Federation [Online], [Retrieved December 20, 2019], http://www.kremlin.ru/acts/bank/41 919

- Report on the Russian economy. November 2017 (\#38). [Online], [Retrieved December 20, 2019], http://rusipoteka.ru/files/analytics/w orldbank/ekonomika_rossii_38.pdf

- Review of unauthorized transfers of funds (2016). Official site of the Central Bank of the Russian Federation. [Online], [Retrieved December 20, 2019],

http://www.cbr.ru/Content/Documen t/File/84814/survey_transfers_16.pdf

- Review of unauthorized transfers of funds (2017). Official site of the Central Bank of the Russian Federation. [Online], [Retrieved December 20, 2019],
http://www.cbr.ru/Content/Documen t/File/84813/survey_transfers_17.pdf

- Review of unauthorized transfers of funds (2018). Official site of the Central Bank of the Russian Federation. [Online], [Retrieved December 20, 2019], https://www.cbr.ru/Content/Docume nt/File/62930/gubzi_18.pdf

- Review of unauthorized transfers of funds (2019). Official site of the Central Bank of the Russian Federation. [Online], [Retrieved July 09, 2020], https://www.cbr.ru/Content/Docume nt/File/103609/Review of transactio ns_2019.pdf

- Winters P.R. (1960) 'Forecasting sales by exponentially weighted moving averages', Management Science, 6(3), 324-342. 